\title{
The use of demineralisation and torrefaction to improve the properties of biomass intended as a feedstock for fast pyrolysis
}

\author{
Tansy Wigley*, Alex C.K. Yip, Shusheng Pang \\ Department of Chemical and Process Engineering, University of Canterbury, New Zealand
}

\begin{abstract}
Pre-treatments of biomass were investigated to reduce its undesirable properties which may affect the quality of fast pyrolysis bio-oil. A pre-treatment sequence was developed in this study to incorporate both biomass demineralisation and torrefaction. Demineralisation was performed by dilute acid leaching, primarily to reduce the inorganic concentration in raw biomass, whereas torrefaction targeted a reduction of the carboxyl, moisture and oxygen content. The liquid produced during torrefaction was recycled back as the leaching reagent for demineralisation. This solution contained dilute organic acids; therefore, the viability of leaching with organic acids (acetic and formic acid) compared to commonly used mineral acids (sulphuric, nitric and hydrochloric acid) was validated. Synthetic leaching solutions reduced the inorganic content in raw biomass from 0.41 wt $\%$ to 0.14 wt $\%$ when leached with $1 \%$ formic acid and to $0.16 \mathrm{wt} \%$ when leached with $1 \%$ acetic acid, which was comparable to leaching with the mineral acids. Recycled torrefaction liquid that contained other acidic compounds in small quantities reduced the inorganic content to $0.14 \mathrm{wt} \%$, suggesting it is effective to use the recycled torrefaction liquid as the leaching solution. From the experimental results, the optimal conditions for biomass torrefaction were $260{ }^{\circ} \mathrm{C}$ for 20 min to minimise the char formation during pyrolysis, based on the increase in the acid-insoluble fraction of the biomass. However, the torrefaction temperature may be increased to $280{ }^{\circ} \mathrm{C}$ if further reductions in acetyl and oxygen content are required. Higher temperatures are associated with severe biomass loss and the initiation of hydrogen loss. It should be noted that even at $280{ }^{\circ} \mathrm{C}$, the oxygen reduction is minimal. If oxygen reduction is the principal target when pre-treating biomass, it is suggested that torrefaction alone is not a suitable method to obtain bio-oil with a low oxygen content due to the low pyrolysis yields obtainable. This study demonstrated that the combined use of demineralisation and torrefaction as biomass pre-treatments has the ability to decrease the inorganic, acetyl and moisture content of biomass, which reduces undesirable catalytic reactions during fast pyrolysis to improve the quality of bio-oil produced.
\end{abstract}

Keywords: demineralisation; acid leaching; torrefaction; pre-treatments; pyrolysis 


\section{Introduction}

Pinus radiata residues are a major by-product of the wood processing industry in New Zealand. In 2001, approximately $1.3 \mathrm{Mm}^{3}$ of wood processing residues remained unused and additional forest residues were not extracted [1]. New Zealand already has many sources of renewable electricity (such as solar, hydro, wind, geothermal and wave power [2,3]). It would be beneficial if a transportation fuel could be produced from the wood residues. Since conversion of softwoods to ethanol is not currently effective [4], focus should be placed on processes such as gasification and fast pyrolysis.

Fast pyrolysis is a thermal process in which biomass polymers are fragmented into light compounds that are able to volatise, thereby producing a product referred to as bio-oil. High heating rates and short vapour residence times employed during fast pyrolysis are preferred to maximise the liquid yield, opposed to slow pyrolysis which enhances char production [5]. The focus for bio-oil production is typically as an alternative to petroleum transportation fuels; however, the high acidity, reactivity, solids content, water content, viscosity and distillation residue restrict the direct use of bio-oil in combustion engines. The high oxygen content of biomass is reflected in the biooils elementary composition, subsequently decreasing its heating value and stability during storage or upon heating. The water content can reach $30 \mathrm{wt} \%$, further decreasing the heating value to approximately half that of petroleum fuels. Typical properties for bio-oils are summarised and compared to those of a heavy fuel oil in Table 1.

Upgrading crude bio-oil through either catalytic cracking or hydroprocessing has been extensively studied [14-27], however, the upgrading process is complicated due to the complexity of the biooil, resulting in low yields and high processing costs. Pre-treating biomass prior to pyrolysis has the potential to improve the quality of crude pyrolysis bio-oil and thus, increase the efficiency of upgrading via catalytic cracking and hydroprocessing processes through reduced reactor clogging and catalyst deactivation. The approach of combining demineralisation and torrefaction as pretreatments has the capability to reduce the oxygen, carboxyl, water and ash content of biomass, subsequently decreasing the negative attributes of bio-oil that limit the efficiency of conventional refining techniques. If small, de-centralised pyrolysis plants could directly produce bio-oil of sufficient quality, the bio-oil could then be transported to existing petroleum refineries for coprocessing with petroleum crude. Figure 1 presents a simplified version of the proposed system. The primary objective of this paper was to investigate the effectiveness of pre-treatments for reducing the negative attributes of biomass for subsequent fast pyrolysis. 
In the pre-treatment stages, biomass is initially demineralised during acid leaching, followed by the removal of excess moisture. Biomass is then torrefied, which also represents the drying stage. The liquid produced during torrefaction mainly contains water and organic acids therefore, this liquid is recycled back into the demineralisation unit as the acid leaching reagent. The use of dilute organic acids $(<1 \%)$ compared to commonly used mineral acids has not been reported so far; only $10 \%$ acetic acid solutions have been tested previously [28]; therefore the secondary objective of this study was to compare the efficiency for demineralisation with organic acids to mineral acids.

\section{$1.1 \quad$ Acid leaching}

Demineralisation typically involves leaching biomass in water or a dilute acid to reduce the inorganic content (ash). It is well documented that inorganics catalyse dehydration and cracking reactions during pyrolysis, lowering the bio-oil quality [29-33]. Additionally, inorganics facilitate coke formation during the catalytic upgrading of bio-oil. Alkali and alkaline earth metals (AAEMs) are typically considered as detrimental compounds in ash. Encinar et al [34] demonstrated that certain transition metals actually decreased the bio-oil yield more than common AAEMs. Nonmetals and halogens (with the exception of silica, which is generally considered inert [35]) can also have a catalytic effect during pyrolysis; therefore, the inorganics targeted during demineralisation were considered as the total inorganic fraction, assuming that silica decreases proportionally to the other elements.

Previous studies indicate that water washing cannot fully remove inorganics from biomass, suggesting that they are present in at least two forms in biomass; either soluble salts or as cations bound to reactive sites in biomass. The latter is most likely as functionalities of cellulose or of acid groups associated with lignin, hemicellulose and extractives. Soluble salts can be removed through simple water leaching, whereas cations require the presence of an acid for ion exchange to occur [29]. The removal of soluble salts via water leaching has been reported to have negligible effect on the bio-oil yield and composition. Cations are bound more tightly to biomass polymers and are thought to interact more readily during pyrolysis by facilitating dehydration and cracking reactions. The removal of acid-soluble cations typically decreases the amount of pyrolytic water, increases the bio-oil yield and significantly alters its composition, primarily by increasing the levoglucosan yield $[29,36]$.

\subsection{Torrefaction}

Torrefaction is a mild version of slow pyrolysis, characterised by slow heating rates, long residence times and temperatures between 200 and $320^{\circ} \mathrm{C}$. The process is relatively new, with development aimed at increasing the energy density of biomass for pelletising [37-39]. The predominant product 
is a darkened biomass, with minor by-products of a liquid and non-condensable gas [40].

Torrefaction can be classified as mild, moderate or severe depending on the temperature and residence time. During mild torrefaction $\left(<220^{\circ} \mathrm{C}\right)$, non-reactive drying and particle shrinkage occur initially, followed by reactive drying, bond breaking, and volatilisation of lipophilic extractives and other light compounds [39]. Moderate torrefaction (220 to $\left.250{ }^{\circ} \mathrm{C}\right)$ is distinguished by the release of water, $\mathrm{CO}, \mathrm{CO}_{2}, \mathrm{CH}_{4}$, light volatiles and organic acid [41]. Under severe torrefaction conditions ( $>250^{\circ} \mathrm{C}$ ) the majority of hemicellulose is decomposed, with cellulose and lignin decomposition initiating when residences times are prolonged [37]. The fibrous biomass structure is destroyed during torrefaction. This reduces the energy for grinding by up to $90 \%$ [41]. The solid product from torrefaction exhibits increased particle spherically when ground, which improves the flow characteristics and increases the bulk density [38, 42-44].

Several authors have considered torrefaction as a pre-treatment for pyrolysis biomass [37, 41, 4548]. It was reported that the quality of the bio-oil improved due to a reduced content of water, oxygen, organic acids and light components [45]. Meng et al. [41] observed that the bio-oil under consideration was rich in pyrolytic lignin and anhydrosugars and low in light oxygenates and aldehydes. Chang et al. [47] reported that the levoglucosan yield increased after torrefaction, and speculated that this was caused by the reduction of catalytic interactions between the major biomass components resulting from the slightly disturbed wood structure. Under severe torrefaction conditions, the total liquid yield (torrefaction plus pyrolysis) decreases due to the formation of stable carbon-carbon cross-links during torrefaction that can undergo further polycondensation reactions to form char during pyrolysis [48]. Cross-links are formed when hydroxyl groups are removed during dehydration reactions. Adjacent cross-links form stable compounds that appear as lignin in the fibre analysis; therefore, the degree of cross-linking can be determined by the increase in acid insoluble fibres during biomass hydrolysis $[47,49]$.

\section{Experimental}

\subsection{Materials}

Pinus radiata wood chips ( $<6 \mathrm{~mm}$ ) were obtained from a local sawmill near Christchurch, New Zealand. After the chips were received, they were dried in a controlled room with a relative humidity of $50 \%$ and temperature of $40{ }^{\circ} \mathrm{C}$, after which the final biomass moisture content was $8.4 \%$ (dry basis). The dried biomass was then knife-milled to $<2 \mathrm{~mm}$ and sieved to remove the fines with diameters of less than $295 \mu \mathrm{m}$. Removal of the fines reduced errors during the pretreatments, as these could become embedded in, or permeate through the filters. For investigations 
of the effect of the particle size during leaching, particles up to $6 \mathrm{~mm}$ were used, as received.

Finally, the dried biomass was stored in air-tight containers until use.

\subsection{Acid leaching}

Prior to acid leaching, the biomass was further dried overnight in an oven at $105{ }^{\circ} \mathrm{C}$ to remove residual moisture and then cooled in a desiccator. Leaching experiments were carried out in capped $2 \mathrm{~L}$ conical flasks. A total of $700 \mathrm{~mL}$ of leaching solution was added to the flask, and $70 \mathrm{~g}$ of ovendry biomass was added to this solution. The flasks containing biomass and leaching solution were heated using magnetic hot plates with a stirring speed of $250 \mathrm{rpm}$. The leaching reagents used are listed in Table 2, and the experiments were carried out at internal liquid temperatures of $30^{\circ} \mathrm{C}$ and $90{ }^{\circ} \mathrm{C}$, respectively, for $4 \mathrm{~h}$ unless otherwise stated. After the leaching was completed, samples were neutralised with deionised water under vacuum using a Buchner funnel with a poly-cotton filter. Neutralised biomass was dried in an oven overnight at $105{ }^{\circ} \mathrm{C}$ and then analysed for polymer composition and inorganic elements. Three duplicates were averaged for each reagent.

\subsection{Torrefaction}

A $300 \mathrm{~mL}$ Gallenkamp bomb calorimeter was modified for torrefaction experiments. Two $1 / 4$ inch Swagelok fittings were welded to the top of the bomb, and these fittings were used to attach carrier gas and vapour removal tubes. Pressure was monitored with a manual pressure gauge (in case of line blockage). The internal temperature was monitored using a type $\mathrm{K}$ thermocouple. A single pass counter-current glass condenser ( $215 \mathrm{~mm}$ long and $6 \mathrm{~mm}$ in internal diameter) was used to condense vapours exiting the reactor. Condensed liquor entered a $100 \mathrm{~mL}$ flask with a cotton wool filter at the top which captured persistent vapours and aerosols. The operational temperature limit for the bomb was $316^{\circ} \mathrm{C}$. The reactor was heated from below using a magnetic hot plate with a 40 $\mathrm{mm}$ thick concentric aluminium block on top to increase the heat transfer rate up the sides of the reactor. A flea containing four $15 \mathrm{~mm}$ in diameter and $5 \mathrm{~mm}$ thick samarium cobalt magnets was designed with the addition of a paddle to provide agitation of the biomass during torrefaction. Employment of the stirrer increased the amount of biomass treated per run to $37.5 \mathrm{~g}$, and improved the consistency of the torrefied biomass. The moisture content of all samples prior to torrefaction was $25 \%$ to simulate torrefaction representing the drying stage (25\% was used, as this value is near the fibre saturation point for Pinus radiata). Three duplicates were averaged for each run.

\subsection{Combined acid leaching and torrefaction}

In order to optimise the combined pre-treatment of biomass, all of the $1 \%$ leached samples listed in Table 2 were torrefied at $240{ }^{\circ} \mathrm{C}$ for $20 \mathrm{~min}$. Samples were dried after leaching to obtain accurate yields but the moisture content was then increased to $25 \%$ prior to torrefaction. Next, $1 \%$ acetic 
acid leached samples (at $30{ }^{\circ} \mathrm{C}$ ) were torrefied at temperatures between 240 and $280{ }^{\circ} \mathrm{C}$ at $10{ }^{\circ} \mathrm{C}$

increments. Figure 2 provides an overview of the pre-treating process and apparatus.

Separate experiments were conducted by recycling the torrefaction liquid as the demineralisation solution. The results obtained from these experiments were compared to those obtained with $1 \%$ acetic acid leached biomass. The liquid was collected from 5 torrefaction experiments at $240{ }^{\circ} \mathrm{C}$, each with $37.5 \mathrm{~g}$ of biomass (moisture content of $25 \%$ ); these aliquots were combined to yield a total of approximately $35 \mathrm{~mL}$ of leaching reagent with an acetic acid concentration of $1.65 \%$. The liquid was then diluted to a $\mathrm{pH}$ of 2.75 which is equivalent to a $1 \%$ acetic acid solution, yielding a total volume of $50 \mathrm{~mL}$, to which $5 \mathrm{~g}$ of dry biomass was added, and the solution was leached at 30 ${ }^{\circ} \mathrm{C}$ for $4 \mathrm{~h}$.

\subsection{Analysis}

ICP-OES: $300 \pm 10 \mathrm{mg}$ of biomass was digested in $2.5 \mathrm{~mL}$ of nitric acid and $2.5 \mathrm{~mL}$ of $30 \%$ hydrogen peroxide in a CEM MARS Xpress microwave digester. The temperature was ramped to $90{ }^{\circ} \mathrm{C}$ over $15 \mathrm{~min}$, held for $5 \mathrm{~min}$, then ramped again to $180{ }^{\circ} \mathrm{C}$ over $10 \mathrm{~min}$ and held for $15 \mathrm{~min}$. The digested samples were analysed using a Varian 720 ICP-OES at Lincoln University in Christchurch.

Elemental analysis: The carbon, hydrogen, oxygen and nitrogen content of the solid samples were determined through complete oxidation [50] with the elementary analyser at CRL Energy Ltd. in Wellington, New Zealand. The carbon, hydrogen, and nitrogen content were determined using standard ISO 29541:2010, and the oxygen content was calculated by the difference.

Biomass ashing: Biomass was heated in a muffle furnace at $625 \pm 10^{\circ} \mathrm{C}$ for at least $16 \mathrm{~h}$. Due to the inherent variability in biomass and possible bark and stone contamination, the analysis result for each sample was an average value from 9 repetitions. The residence time was relatively long (approximately $6 \mathrm{~h}$ is common $[16,51]$ ) because a constant weight could not be assessed without at least $2 \mathrm{~h}$ of cooling before removing the sample from the furnace.

Biomass structural analysis via hydrolysis: Biomass samples were extracted prior to hydrolysis using an automatic Dionex ASE 350 extractor with ethanol as the solvent. Conditions for extraction followed standard NREL/TP-510-42619. In brief, samples were heated in $33 \mathrm{~mL}$ extraction cells to $100{ }^{\circ} \mathrm{C}$ at $1,500 \mathrm{psi}$ for $7 \mathrm{~min}$, followed by flushing with $150 \mathrm{vol} \%$ of ethanol. Three cycles were repeated for each sample. After this, samples were dried overnight to obtain the extractive yield. The procedure for hydrolysis followed standard NREL/TP-510-42618, with slight alterations. In brief, $0.30 \pm 0.01 \mathrm{~g}$ of dry biomass was hydrolysed for $1 \mathrm{~h}$ in $3 \mathrm{~mL}$ of $72 \%$ sulphuric acid and 
stirred every $10 \mathrm{~min}$. The samples were diluted to $4 \%$ sulphuric acid by adding $84 \mathrm{~mL}$ of deionised

water and then heated to $113{ }^{\circ} \mathrm{C}$ (1.5 bar) in Duran ${ }^{\circledR}$ GL45 Pressure Plus laboratory glass bottles for 90 min. After hydrolysis was completed, the samples were vacuum filtered using Buchner funnels, and the liquor was collected for HPLC and UV-Visible spectrophotometer analysis. The remaining hydrolysis solids (Klason lignin) were washed with deionised water until a neutral $\mathrm{pH}$ was reached before being dried overnight at $105{ }^{\circ} \mathrm{C}$. Finally, the samples were cooled in a desiccator and weighed to obtain the Klason lignin yield. A portion of the inorganics in biomass dissolve during hydrolysis [52]; therefore, the lignin was ashed following hydrolysis, and the lignin yield was adjusted accordingly.

$U V$-Visible spectrophotometer: The hydrolysis liquor was analysed for acid-soluble lignin by absorbance at $240 \mathrm{~nm}$ with an absorptivity of $12 \mathrm{Lg}^{-1} \mathrm{~cm}^{-1}$. A wavelength of $280 \mathrm{~nm}$ is commonly used [53-55], but degraded carbohydrate products such as furfural and hydroxymethylfurfural strongly absorb at a wavelength of $280 \mathrm{~nm}$, whereas a wavelength of $240 \mathrm{~nm}$ results in minimal absorbance. Only total lignin yields are reported, representing the sum of Klason and acid-soluble lignin.

HPLC: The hydrolysis liquor was neutralised with calcium carbonate and filtered through $0.22 \mu \mathrm{m}$ nylon syringe filters prior to the HPLC analysis. A Supelcogel C-610H carbohydrate column was used for the sugar and organic acid analysis with a refractive index detector and a mobile phase of $0.1 \%$ phosphoric acid. The column temperature was maintained at $30{ }^{\circ} \mathrm{C}$. The sample injection size was $17 \mu \mathrm{L}$ with a residence time of $20 \mathrm{~min}$. Standards were run for cellobiose, glucose, xylose, galactose, arabinose, mannose, acetic acid, formic acid, levulinic acid and methanol. The column was chosen for optimal carboxylic acid analysis opposed to optimal sugar analysis, as accurately quantifying the acids content was deemed more important.

\section{Results and Discussion}

\subsection{Biomass Leaching}

Leaching reagents: The total yields and structural analysis of biomass samples following leaching with different reagents are presented in Table 3. During leaching, biomass sugar polymers depolymerised if conditions were sufficiently severe for hydrolysis to initiate. The mass yields at $90{ }^{\circ} \mathrm{C}$ were related to the $\mathrm{pH}$ of the leaching solution (in decreasing order: hydrochloric, nitric, sulphuric, formic and acetic acid). Mineral acids all reduced the biomass yield significantly during leachings at $90{ }^{\circ} \mathrm{C}$. Leaching with hydrochloric acid was the most severe, with hemicellulose being partially hydrolysed and the acetyl concentration significantly reduced. Mass yields from various leaching experiments with organic acids and water at $90{ }^{\circ} \mathrm{C}$ were approximately the same, 
indicating that water soluble extractives were removed and minimal carbohydrate degradation occurred.

The inorganic fraction in biomass was reduced from 0.45 to $0.27 \mathrm{wt} \%$ with water washing alone, indicating that approximately $40 \%$ of the inorganics in biomass are present as soluble salts. Reduction of the inorganics ionically bound to biomass was accomplished using dilute acid solutions. The remaining inorganics were inaccessible within the wood matrix and could not be removed even with severe leaching procedures for Pinus radiata. Further reduction in inorganic content has been reported by other researchers with different feedstocks $[28,56]$. The reduction of inorganics was slightly better for mineral acids compared to the organic acids at $30^{\circ} \mathrm{C}$. Increasing the leaching temperature to $90{ }^{\circ} \mathrm{C}$ increased the removal for the organic acids but had only a minor effect for the mineral acids, partially due to the increased mass loss. This result indicates that the reduction in inorganics can be achieved using the dilute organic acids obtained from torrefaction.

The ICP-OES results given in Table 4 indicate that only $\mathrm{S}, \mathrm{P}, \mathrm{Na}$ (and $\mathrm{Zn}$ for formic acid) were reduced to the same degree by organic acids as by mineral acids at $30^{\circ} \mathrm{C}$. The results at $90{ }^{\circ} \mathrm{C}$ imply that the alkali metals ( $\mathrm{K}$ and $\mathrm{Na}$ ) were reduced approximately equally with all leaching acids but that the alkaline earth metals ( $\mathrm{Mg}$ and $\mathrm{Ca}$ ) were not. The result could be beneficial, as alkaline earth metals have been used as catalysts for de-oxygenation during pyrolysis [57, 58], by favouring depolymerisation reactions over dehydration reactions [59]. Sulphuric acid caused a large increase in S, indicating that either some of the acid was not washed out during the neutralising step or S became incorporated into the biomass and thus could not be removed through water washing alone. This suggests a potential benefit for using organic acids compared to some mineral acids during leaching.

A mass balance for the elements in biomass leached with $1 \%$ acetic acid at $30{ }^{\circ} \mathrm{C}$ is given in Table 5. The discrepancy between the calculated mass balance for the elements removed from the biomass and the experimentally measured values in the leachate indicate that additional ions were present in the leachate which were not generated from the biomass. These could originate from the acetic acid or deionised water, but both sources would be minimal based on the assay of the raw solutions. The most likely introduction of additional ions would be from either the vessel in which the leaching solution was collected or stored.

Effect of organic acid concentration: The concentration of acetic and formic acid was varied to determine the minimal acid loading required to reduce the inorganic content. Figure 3 indicates that the effect of low acid concentrations was more pronounced for acetic acid compared to formic acid, but increasing the concentration above $1 \%$ had minimal effect for either acid when the biomass was 
leached at $30{ }^{\circ} \mathrm{C}$ for $4 \mathrm{~h}$. This result implies that a fraction of the inorganics present in biomass

cannot be removed at $30^{\circ} \mathrm{C}$ with formic or acetic acid under the given leaching conditions. This may be correlated with to the $\mathrm{pH}$ obtained with the leaching solution as shown in Figure 4. It appears that the inorganic reduction is related to the $\mathrm{pH}$ of the leaching solution, regardless of the actual acid type. Figure 4 can be used to predict the inorganic content after leaching for any given acid leaching reagent under the same leaching conditions.

Effect of leaching residence time: The residence time for $1 \%$ acetic acid leached samples was assessed between 1 and $8 \mathrm{~h}$. The total inorganic fraction of the biomass following leaching is given in Figure 5. The results indicate that at least $4 \mathrm{~h}$ is required to reduce the ion concentration significantly, but increasing in the residence time beyond $4 \mathrm{~h}$ provides minimal benefit.

Effect of biomass particle size: Because torrefaction significantly reduces grinding costs, it would be beneficial for leaching and torrefaction to be carried out on larger chips; afterward, a final size reduction can be implemented if necessary. Wood chips with a particle size of $6 \mathrm{~mm}$ or less were leached to compare the efficiency of ion removal to the standard wood chips with a particle size of $2 \mathrm{~mm}$ or less. The samples were leached using $1 \%$ acetic acid at standard conditions $\left(30^{\circ} \mathrm{C}\right.$ for $4 \mathrm{~h}$, stirred at $250 \mathrm{rpm}$ ). It was interesting to find that leaching was slightly more efficient with the larger chips and reduced the inorganic content to $0.15 \pm 0.02 \mathrm{wt} \%$, indicating that the system was not limited by internal mass transfer. This finding could be because the $6 \mathrm{~mm}$ chips were milled predominantly in the longitudinal direction, whereas the $2 \mathrm{~mm}$ chips were knife-milled equally in the longitudinal, radial and tangential directions. Knife milling against the grain could close elongated tracheid cell ends, thereby reducing the mass transfer rate of leaching solution into the biomass and the rate of ion transfer out. Figure 6 provides a representation of the different chip sizes used. The $6 \mathrm{~mm}$ chips could reach $20 \mathrm{~mm}$ the longitudinal direction due to the chipping technique used, whereas the $2 \mathrm{~mm}$ chips were approximately equal in all directions.

\subsection{Torrefaction}

Effect of residence time: The residence time for torrefaction at $245{ }^{\circ} \mathrm{C}$ was varied from 15 to 120 min, with the results displayed in Figure 7. The acetyl content decreased as the residence time was extended up to $120 \mathrm{~min}$. The decrease was not significantly large to warrant an extension beyond 20 min due to the additional heating costs and decrease in biomass carbohydrate content. Incomplete moisture removal may occur when residence times are not sufficiently long; therefore 20 min was considered optimal.

Effect of temperature: Torrefaction targets the reduction of highly oxygenated side braches associated with hemicellulose and lignin, particularly carboxyl compounds. It is reported that a 
harsher severity of torrefaction by increasing the temperature enhances the cleavage of acetyl

branches associated with galactoglucomannan in the hemicellulose fraction of softwood biomasses $[60,61]$. Figure 8 indicates a reduction in acetyl branches from $1.51 \mathrm{wt} \%$ to $0.43 \mathrm{wt} \%$ when comparing raw biomass to biomass torrefied at $290{ }^{\circ} \mathrm{C}$ for $20 \mathrm{~min}$. Mild pyrolysis occurs when torrefaction conditions are severe, thereby decreasing the overall potential bio-oil yield during pyrolysis. Furthermore, severe torrefaction initiates the formation of cross-linked carbohydrate polymers that are stable under pyrolysis conditions, leading to char formation instead of further polymeric breakdown to bio-oil. This effect was quantified by the 'apparent' increase in lignin after a full acid hydrolysis of the biomass as cross-linked sugar polymers are acid insoluble. At $290{ }^{\circ} \mathrm{C}$, the total 'apparent lignin' content reached $59 \mathrm{wt} \%$; the pyrolytic char yield could not be reliably predicted from this result, but it may be close to the yield from true lignin, which can exceed $46 \%$ $[62]$.

The structural analysis of the torrefied biomass also indicated that the acid-soluble fraction of lignin increased for torrefied biomass, possibly due to the production of compounds during hydrolysis that have the same UV-Visible absorbance as lignin by slightly altered cellulose and hemicellulose polymers. Alternatively, the acid soluble lignin content could indicate the partial degradation of lignin during torrefaction, which would increase the acid soluble fraction.

An elemental analysis of torrefied biomass is presented in Table 6. Elemental analysis was another method used to quantify the severity of torrefaction. It also provides an indication of the oxygen reduction relative to the hydrogen reduction. Because pyrolysis is a hydrogen deficient process [63], the removal of oxygen through the production of water is undesirable during pre-treating; furthermore, such removal leads to severely cross-linked biomass. Most research suggests that there is no chemical elimination of water from biomass below $220^{\circ} \mathrm{C}[59]$, thus hydroxyl groups are not removed from sugar polymers to produce a cross-linked structure. However, carboxyl cleavage from hemicellulose and oxygen reduction were minimal in this low temperature regime. Higher temperatures were required for significant acetyl reduction and oxygen reduction, as well as to breakdown the fibrous structure of the biomass. Thus, the optimum torrefaction temperature was proposed to be approximately $250{ }^{\circ} \mathrm{C}$ to prevent significant biomass loss during torrefaction $(<10 \%)$ and to minimise the char yield during pyrolysis. The torrefaction temperature could be increased to a maximum of $280^{\circ} \mathrm{C}$ (before hydrogen loss becomes significant) if oxygen reduction and acetyl removal were considered more important than maintaining high bio-oil yields in the subsequent pyrolysis. Significant oxygen reduction, however, is difficult to achieve during torrefaction without severe biomass losses. For example, after torrefaction at $290{ }^{\circ} \mathrm{C}$ with a biomass 
yield of $65.3 \mathrm{wt} \%$ the oxygen content was only decreased to $35.7 \%$. Therefore, it is suggested that torrefaction alone is not a suitable method to obtain a low oxygen bio-oil at reasonable yields.

\subsection{Combined acid leaching and torrefaction}

Biomass leached at $30^{\circ} \mathrm{C}$ and $90{ }^{\circ} \mathrm{C}$ (leaching reagents and biomass analysis given in Table 3) was torrefied at $240{ }^{\circ} \mathrm{C}$ for $20 \mathrm{~min}$ to determine the effect of leaching temperature on the subsequent effect torrefaction. The yields after torrefaction are provided in Table 7. The liquid yields varied on a dry basis due to the retention of a fraction of the condensate in the condenser. For the $1 \%$ nitric acid solution at $90{ }^{\circ} \mathrm{C}$, it appeared that there was no liquid produced but the collected solution still had a low $\mathrm{pH}$ and was the normal light yellow colour. Yield deviations from the torrefaction of raw wood appear minimal for leaching procedures at $30^{\circ} \mathrm{C}$, although slight deviations were observed when the leaching temperature was increased to $90{ }^{\circ} \mathrm{C}$. There was a general trend of decreased severity of torrefaction with slightly higher biomass yields and a higher $\mathrm{pH}$ of the torrefaction liquid.

The acetyl content in the biomass after the combined pre-treatments is given in Table 8. The relative reduction in acetyl compounds during torrefaction was lower for samples leached at $90{ }^{\circ} \mathrm{C}$ compared to samples leached at $30{ }^{\circ} \mathrm{C}$ or biomass not previously leached. Torrefaction may appear less severe due to the loss of easily cleavable compounds during leaching, especially for the mineral acids. There was no reduction in the acetyl content for DI-water leached biomass at $90{ }^{\circ} \mathrm{C}$; therefore, the decreased acetyl removal cannot be solely attributed to previous cleavage. Inorganics could play a catalytic role in acetyl cleavage during torrefaction. Acetyl side-branches of galactoglucomannan are easily cleaved by alkali species during leaching [61]; a similar mechanism may apply during torrefaction. However, the inorganic reduction for DI-water leaded biomass at 90 ${ }^{\circ} \mathrm{C}$ was considerably less than the reduction by all of the acid leaching reagents at $30{ }^{\circ} \mathrm{C}$. Therefore, elevated temperatures during demineralisation must alter the morphology of the biomass and make it less susceptible to acetyl degradation during torrefaction. Performing torrefaction following biomass leaching at $90{ }^{\circ} \mathrm{C}$ would provide minimal benefits; instead biomass leaching at $30^{\circ} \mathrm{C}$ is recommended when both acid leaching and torrefaction are employed as biomass pre-treatments.

Sample leached with $1 \%$ acetic acid were torrefied between 240 and $280{ }^{\circ} \mathrm{C}$ at $10{ }^{\circ} \mathrm{C}$ increments for $20 \mathrm{~min}$. The results are compared to the torrefaction of raw biomass in Table 9 . The severity of torrefaction appears to be less affected by the leaching pre-treatment as the torrefaction temperature increases. The overall biomass loss from acid leaching and torrefaction combined was still less than the loss for torrefaction alone. The acetyl reduction improved, possibly due to weakening of biomass polymers, which facilitated cleavage during torrefaction. Sugar degradation was reduced 
when samples had been previously leached, and therefore, the oxygen content was higher due to the high oxygen content in cellulose and hemicellulose; approximately $49 \mathrm{wt} \%$ and $54 \mathrm{wt} \%$ respectively [8]. When acid leaching precedes torrefaction, the temperature of torrefaction can be increased to $260{ }^{\circ} \mathrm{C}$ while still maintaining high overall biomass yields, but with a further reduction in acetyl content to $0.83 \mathrm{wt} \%$ and lower lignin and oxygen contents compared to biomass solely torrefied at $250{ }^{\circ} \mathrm{C}$.

Recycling torrefaction liquor: Liquor from 5 torrefaction runs $\left(240{ }^{\circ} \mathrm{C}\right.$ for $\left.20 \mathrm{~min}\right)$ was combined and diluted to obtain a solution with a $\mathrm{pH}$ of 2.75 . This solution was used to leach biomass at $30{ }^{\circ} \mathrm{C}$ for $4 \mathrm{~h}$. The inorganic content in the leached biomass was reduced to $0.14 \pm 0.02 \mathrm{wt} \%$, which was lower than for biomass leached with $1 \%$ acetic acid. This low inorganic content could be due to the presence of other acidic compounds in small quantities, which increased cation removal. The torrefaction liquor was qualitatively analysed using gas chromatography-mass spectrometry (GCMS), which indicated the presence of hexanoic, heptanoic, octanoic and nonanoic acid in small quantities. Torrefaction does not produce adequate liquid to leach an equivalent amount of biomass; therefore, the leachate would need to be recycled from acid leaching. The leachate could be regeneration using pyrolysis chars, because their hydrophilic surface is suitable for removing ions from water [64]. A portion of the leachate is lost during the regeneration; this would be replenished with the new torrefaction liquor. The recycling and regeneration of leachate would minimise environmental issues concerning the disposal of the mobile phase after leaching due to possible trace amounts of hazardous elements.

Demineralisation procedures require subsequent rinsing of the biomass to ensure complete removal of the leaching reagent. Rinsing is necessary because mineral acids reduce yields during pyrolysis and increase pyrolytic water through dehydration, condensation and cross-linking reactions [65]. Rinsing is also necessary because acids in the feed material directly influence the $\mathrm{pH}$ of the bio-oil. The influence organic acids during pyrolysis is ambiguous, but preliminary pyrolysis experiments indicate that the bio-oil yield is significantly reduced in their presence. This could lead to economical drawbacks at larger scales due to the amount of water required for rinsing and disposal of the contaminated solution during the rinsing process. No rinsing step is required in the proposed pre-treatment sequence, as the organic acids will volatise during torrefaction.

Effect of pre-treatments on pyrolysis: Detailed pyrolysis results will be reported in a subsequent paper but in brief; the dynamics of fast pyrolysis were altered through the targeted reduction of three natural biomass catalysts (moisture, inorganics and organic acids). The bio-oil yield increased by $20 \%$ on a water free basis. Pyrolytic water was significantly lower through decreased 
dehydration reactions, and with no moisture in the feed, the total water content of the bio-oil was

under 5\%. The acetic acid content in the bio-oil was reduced by $96 \%$ through the removal of acetyl branches prior to pyrolysis, additionally carboxylic acids produced during pyrolysis decreased due to minimal ring opening and cracking reactions of primary products catalysed by inorganics [66]. The average molecular weight and pyrolytic lignin content of the oil decreased due to reduced repolymerisation reactions during pyrolysis. The inorganic content of the bio-oil decreased and the stability improved. However, the oxygen content of the bio-oil reflected that of the feedstock, therefore was only marginally decreased for pyrolysis of pre-treated biomass. Further research will investigate other techniques for reducing the oxygen content of the bio-oil without incurring significant mass losses. Together, these improvements to the bio-oil properties may increase the efficiency when refining bio-oil using current technologies such as common fluid cracking catalysts or hydroprocessing.

\section{Conclusions}

This paper investigated the individual effects of demineralisation and torrefaction on Pinus radiata biomass, and the integrated effects of combining the two pre-treatments. This study proposed to recycle the liquid fraction produced during torrefaction as the leaching reagent; therefore, weak organic acids were compared to the commonly used mineral acids in terms of their capacity to reduce the inorganic fraction during demineralisation. The reduction capacity was slightly lower at $30{ }^{\circ} \mathrm{C}$ but equivalent when samples were leached at $90{ }^{\circ} \mathrm{C}$. When the torrefaction liquid was diluted to a $\mathrm{pH}$ of 2.75 and recycled back for leaching, the reduction in the inorganic content was similar to that of biomass leached with formic acid.

Torrefaction targeted a reduction in the acetyl and oxygen contents and complete moisture removal from the biomass, although it was realised that only slight oxygen reductions could be achieved without large biomass losses from torrefaction alone. Prolonged residence times during torrefaction had a minimal effect on the severity of torrefaction compared to the effect produced by increasing the temperature. Severe torrefaction (temperatures above $250{ }^{\circ} \mathrm{C}$ ) was associated with a large mass loss and increased the apparent lignin content of the biomass; therefore when torrefaction was the sole pre-treatment, the optimal temperature was $250{ }^{\circ} \mathrm{C}$. The temperature of torrefaction could be increased to a maximum of $280{ }^{\circ} \mathrm{C}$ if the quality of the pyrolysis oil required further acetyl, oxygen and water reduction, but such improvements would occur at the expense of bio-oil yields. Above $280{ }^{\circ} \mathrm{C}$, cross-linking of the biomass was excessive, and hydrogen was lost due to the formation of water; therefore, such temperatures are not recommended. 
When $1 \%$ acetic acid leached biomass was torrefied between 240 and $280{ }^{\circ} \mathrm{C}$, the severity of

torrefaction decreased in terms of biomass, oxygen and sugar loss; therefore, the optimal torrefaction temperature was increased to $260{ }^{\circ} \mathrm{C}$, which lead to a further reduction in the acetyl content of the biomass.

\section{Acknowledgements}

The authors would like to acknowledge the New Zealand Ministry of Business, Innovation and Employment (MBIE) for funding this research. The technical personnel at the University of Canterbury are also thanked for their part in the construction and commissioning of experimental equipment.

\section{References}

1. Roughton, E., Energy from woody biomass in New Zealand. 2001, Energy Efficiency and Conservation Authority: Wellington.

2. McKendry, P., Energy production from biomass (part 2): conversion technologies. Bioresour Technol, 2002. 83(1): p. 47-54.

3. Bertram, G. and D. Clover (2010) Kicking the fossil-fuel habit: New Zealand's ninety percent renewable target for electricity. 40.

4. Suckling, I., et al. An efficient process for the enzymatic conversion of radiata pine to sugars suitable for biofuel production in New Zealand ddvanced biofuels research network. 2013. Auckland.

5. Bridgwater, A.V., An introduction to fast pyrolysis of biomass for fuels and chemicals, in Fast Pyrolysis of Biomass: A Handbook, A.V. Bridgwater, Editor. 1999, CPL Press: Newbury. p. 1-13.

6. Huber, G.W., S. Iborra, and A. Corma, Synthesis of transportation fuels from biomass: chemistry, catalysts, and engineering. Chemical Reviews, 2006. 106(9): p. 4044-4098.

7. Oasmaa, A., E. Kuoppala, and Y. Solantausta, Fast pyrolysis of forestry residue. 2. physicochemical composition of product liquid. Energy \& Fuels, 2003. 17(2): p. 433-443.

8. Bridgwater, A.V. and J.P. Diebold, Overview of fast pyrolysis of biomass for the production of liquid fuels, in Fast Pyrolysis of Biomass: A Handbook, A.V. Bridgwater, Editor. 1999, CPL Press Newbury. p. 14-32.

9. Diebold, J.P., et al., Proposed specifications for various grades of pyrolysis oils, in Fast Pyrolysis of Biomass: A Handbook, A.V. Bridgwater, Editor. 1999, CPL Press: Newbury Berkshire UK. p. 102114.

10. Bridgwater, A.V., Production of high grade fuels and chemicals from catalytic pyrolysis of biomass. Catalysis Today, 1996. 29(1-4): p. 285-295.

11. Zhang, Q., et al., Review of biomass pyrolysis oil properties and upgrading research. Energy Conversion and Management, 2007. 48(1): p. 87-92.

12. Dayton, D.C., et al., Release of inorganic constituents from leached biomass during thermal conversion. Energy \& Fuels, 1999. 13(4): p. 860-870.

13. Dynamotive, Dynamotive BioOil, in Information Booklet 2012. 2012, Dynamotive Energy Systems Corporation: Canada. p. 28.

14. Zhang, S., et al., Upgrading of liquid fuel from the pyrolysis of biomass. Bioresour Technol, 2005. 96(5): p. 545-550.

15. Şenol, O.I.., T.R. Viljava, and A.O.I. Krause, Hydrodeoxygenation of methyl esters on sulphided

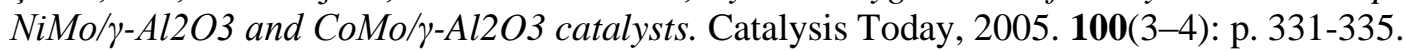

16. Vispute, T.P. and G.W. Huber, Production of hydrogen, alkanes and polyols by aqueous phase processing of wood-derived pyrolysis oils. Green Chemistry, 2009. 11(9): p. 1433-1445.

17. Diebold, J.P., A review of the chemical and physical mechanisms of the storage stability of fast pyrolysis bio-oils. 2000, National Renewable Energy Laboratory: Lakewood, Colorado. 
18. Olazar, M., et al., Pyrolysis of sawdust in a conical spouted-bed reactor with a HZSM-5 catalyst. American Institute of Chemical Engineers. AIChE Journal, 2000. 46(5): p. 1025-1025.

19. Pattiya, A., J.O. Titiloye, and A.V. Bridgwater, Fast pyrolysis of cassava rhizome in the presence of catalysts. Journal of Analytical and Applied Pyrolysis, 2008. 81(1): p. 72-79.

20. Li, H.-y., Y.-j. Yan, and Z.-w. Ren, Online upgrading of organic vapors from the fast pyrolysis of biomass. Journal of Fuel Chemistry and Technology, 2008. 36(6): p. 666-671.

21. Nokkosmäki, M.I., et al., Catalytic conversion of biomass pyrolysis vapours with zinc oxide. Journal of Analytical and Applied Pyrolysis, 2000. 55(1): p. 119-131.

22. Adam, J., et al., In situ catalytic upgrading of biomass derived fast pyrolysis vapours in a fixed bed reactor using mesoporous materials. Microporous and Mesoporous Materials, 2006. 96(1-3): p. 93101.

23. Adjaye, J.D. and N.N. Bakhshi, Production of hydrocarbons by catalytic upgrading of a fast pyrolysis bio-oil. Part I: Conversion over various catalysts. Fuel Processing Technology, 1995. 45(3): p. 161-183.

24. Adjaye, J.D. and N.N. Bakhshi, Production of hydrocarbons by catalytic upgrading of a fast pyrolysis bio-oil. Part II: Comparative catalyst performance and reaction pathways. Fuel Processing Technology, 1995. 45(3): p. 185-202.

25. Vitolo, S., et al., Catalytic upgrading of pyrolytic oils to fuel over different zeolites. Fuel, 1999. 78(10): p. 1147-1159.

26. Luque, R., et al., Efficient aqueous hydrogenation of biomass platform molecules using supported metal nanoparticles on Starbons. Chemical Communications, 2009(35): p. 5305-5307.

27. Karimi, E., et al., Thermal decomposition of acetic and formic acid catalyzed by red mud Implications for the potential use of red mud as a pyrolysis bio-oil upgrading catalyst. Energy \& Fuels, 2010. 24(4): p. 2747-2757.

28. Oudenhoven, S.R.G., et al., Demineralization of wood using wood-derived acid: Towards a selective pyrolysis process for fuel and chemicals production. Journal of Analytical and Applied Pyrolysis, 2013. 103(0): p. 112-118.

29. Scott, D.S., et al., Pretreatment of poplar wood for fast pyrolysis: rate of cation removal. Journal of Analytical and Applied Pyrolysis, 2001. 57(2): p. 169-176.

30. Hallen, R.T., L.J. Sealock, and R. Cuello, Influence of alkali carbonates on biomass volatilization, in Fundamentals of Thermochemical Biomass Conversion, R.P. Overend, T.A. Milne, and L.K. Mudge, Editors. 1985, Elsevier Applied Science Publishers. p. 157-166.

31. Saddawi, A., et al., Commodity fuels from biomass through pretreatment and torrefaction: Effects of mineral content on torrefied fuel characteristics and quality. Energy \& Fuels, 2011. 26(11): p. 6466-6474.

32. Fahmi, R., et al., The effect of lignin and inorganic species in biomass on pyrolysis oil yields, quality and stability. Fuel, 2008. 87(7): p. 1230-1240.

33. Nowakowski, D., et al., Potassium catalysis in the pyrolysis behaviour of short rotation willow coppice. Fuel, 2007. 86(15): p. 2389-2402.

34. Encinar, J.M., et al., Catalyzed pyrolysis of grape and olive Bagasse. Influence of catalyst type and chemical treatment. Industrial \& Engineering Chemistry Research, 1997. 36(10): p. 4176-4183.

35. Jensen, A., et al., TG-FTIR study of the influence of potassium chloride on wheat straw pyrolysis. Energy \& Fuels, 1998. 12(5): p. 929-938.

36. Mourant, D., et al., Mallee wood fast pyrolysis: Effects of alkali and alkaline earth metallic species on the yield and composition of bio-oil. Fuel, 2011. 90(9): p. 2915-2922.

37. Kasparbauer, R.D., The effects of biomass pretreatments on the products of fast pyrolysis, in Mechanical Engineering. 2009, Iowa State University: Ames, Iowa. p. 308.

38. Chen, W.-H., et al., An evaluation on improvement of pulverized biomass property for solid fuel through torrefaction. Applied Energy, 2011. 88(11): p. 3636-3644.

39. Westover, T.L., et al., Impact of thermal pretreatment on the fast pyrolysis conversion of southern pine. Biofuels, 2012. 4(1): p. 45-61.

40. Chen, W.-H., et al., Thermal pretreatment of wood (Lauan) block by torrefaction and its influence on the properties of the biomass. Energy, 2011. 36(5): p. 3012-3021.

41. Meng, J., et al., The effect of torrefaction on the chemistry of fast-pyrolysis bio-oil. Bioresour Technol, 2012. 111(0): p. 439-446.

42. Wang, G., et al., Pretreatment of biomass by torrefaction. Chinese Science Bulletin, 2011. 56(14): p. 1442-1448. 
43. Boardman, R.D., et al., A review on biomass torrefaction process and product properties for energy applications. Industrial Biotechnology, 2011. 7(5): p. 384+.

44. Deng, J., et al., Pretreatment of agricultural residues for co-gasification via torrefaction. Journal of Analytical and Applied Pyrolysis, 2009. 86(2): p. 331-337.

45. Wannapeera, J. and N. Worasuwannarak, Upgrading of woody biomass by torrefaction under pressure. Journal of Analytical and Applied Pyrolysis, 2012. 96(0): p. 173-180.

46. Westerhof, R.J.M., et al., Step-Wise fast pyrolysis of pine wood. Energy \& Fuels, 2012.

47. Chang, S., et al., Characterization of products from torrefaction of sprucewood and bagasse in an auger reactor. Energy \& Fuels, 2012. 26(11): p. 7009-7017.

48. Zheng, A., et al., Effect of torrefaction on structure and fast pyrolysis behavior of corncobs. Bioresour Technol, 2012(0).

49. Yan, W., et al., Thermal pretreatment of lignocellulosic biomass. Environmental Progress \& Sustainable Energy, 2009. 28(3): p. 435-440.

50. Nowakowski, D.J., et al., Lignin fast pyrolysis: Results from an international collaboration. Journal of Analytical and Applied Pyrolysis, 2010. 88(1): p. 53-72.

51. ASTM, Standard test method for ash in biomass. 2007, ASTM International: United States. p. 3.

52. Chen, W.-H., Y.-J. Tu, and H.-K. Sheen, Impact of dilute acid pretreatment on the structure of bagasse for bioethanol production. International Journal of Energy Research, 2010. 34(3): p. 265274.

53. Maekawa, E., T. Ichizawa, and T. Koshijima, An evaluation of the acid-soluble lignin determination in analyses of lignin by the sulfuric acid method. Journal of Wood Chemistry and Technology, 1989. 9(4): p. 549-567.

54. Dence, C.W., The determination of lignin, in Methods in Lignin Chemistry, S. Lin and C. Dence, Editors. 1992, Springer Berlin Heidelberg. p. 33-61.

55. Iiyama, K. and A.F.A. Wallis, An improved acetyl bromide procedure for determining lignin in woods and wood pulps. Wood Science and Technology, 1988. 22(3): p. 271-280.

56. Piskorz, J., et al., Pretreatment of wood and cellulose for production of sugars by fast pyrolysis. Journal of Analytical and Applied Pyrolysis, 1989. 16(2): p. 127-142.

57. Lin, Y., et al., Deoxygenation of bio-oil during pyrolysis of biomass in the presence of CaO in a fluidized-bed reactor. Energy and Fuels, 2010. 24(10): p. 5686-5695.

58. Scott, D.S., J. Piskorz, and D. Radlein, Liquid products from the continuous flash pyrolysis of biomass. Industrial \& Engineering Chemistry Process Design and Development, 1985. 24(3): p. 581-588.

59. Scheirs, J., G. Camino, and W. Tumiatti, Overview of water evolution during the thermal degradation of cellulose. European Polymer Journal, 2001. 37(5): p. 933-942.

60. Aho, A., et al., Catalytic pyrolysis of biomass in a fluidized bed reactor: Influence of the acidity of H-beta zeolite. Process Safety and Environmental Protection, 2007. 85(5): p. 473-480.

61. Hayes, D. Advanced biomass research for beyond the petroleum age. Important Compositional Parameters 2013 [cited 2013 07/09/2013]; Available from:

http://www.carbolea.ul.ie/composition.php.

62. Yang, H., et al., Characteristics of hemicellulose, cellulose and lignin pyrolysis. Fuel, 2007. 86(1213): p. 1781-1788.

63. Barth, T. and M. Kleinert, Motor fuels from biomass pyrolysis. Chemical Engineering \& Technology, 2008. 31(5): p. 773-781.

64. Savova, D., et al., Biomass conversion to carbon adsorbents and gas. Biomass and Bioenergy, 2001. 21(2): p. 133-142.

65. Di Blasi, C., C. Branca, and A. Galgano, Thermal and catalytic decomposition of wood impregnated with sulfur- and phosphorus-containing ammonium salts. Polymer Degradation and Stability, 2008. 93(2): p. 335-346.

66. Wigley, T., S. Pang, and A. Yip. Development of the Fast Pyrolysis Process to Produce a High Quality Liquid Fuel from Woody Biomass. in 20th International Symposium on Analytical and Applied Pyrolysis. 2014. Birmingham, UK 


\section{List of Tables:}

Table 1: Properties of bio-oil compared to a heavy fuel oil and the effects of these properties on the oil's quality

Table 2: Leaching reagents for demineralisation at 30 and $90{ }^{\circ} \mathrm{C}$

Table 3: Composition of biomass after leaching with different leaching acids

Table 4: ICP-OES results for biomass leached at 30 and $90{ }^{\circ} \mathrm{C}$

Table 5: Mass balance of elements for $1 \%$ acetic acid leached biomass at $30{ }^{\circ} \mathrm{C}$

Table 6: Elemental analysis of biomass after torrefaction at varying temperatures

Table 7: Yields from the torrefaction of demineralised biomass

Table 8: Total loss in yield and structural analysis of biomass after demineralisation and torrefaction

Table 9: Comparison between torrefaction of raw biomass and 1\% acetic acid leached biomass 
Table 1: Properties of bio-oil compared to a heavy fuel oil and the effects of these properties on the oil's quality

\begin{tabular}{llll}
\hline Property & $\begin{array}{l}\text { Pyrolysis oil } \\
{[6]}\end{array}$ & $\begin{array}{l}\text { Heavy fuel oil } \\
{[6]}\end{array}$ & Effect on the quality in terms of fuel use \\
\hline HHV $\left(\mathrm{MJkg}^{-1}\right)$ & $14-20$ & 40 & Larger volumes required [7-9] \\
Water content $(\mathrm{wt} \%)$ & $15-30$ & 0.1 & Lowers the heating value, viscosity, density, and ignition rate [10, 11] \\
$\mathrm{pH}$ & $2-3$ & - & Corrosive to pipes and vessels [10, 11] \\
Solids $(\mathrm{wt} \%)$ & $0.2-1$ & 1 & Enhances bio-oil aging, corrosion and equipment blockages [10] \\
Ash $(\mathrm{wt} \%)$ & $0-0.2$ & 0.1 & High temperature corrosion, hard deposits, and bio-oil aging [11, 12] \\
Viscosity $\left(\mathrm{cP}\right.$ at $\left.50^{\circ} \mathrm{C}\right)$ & $40-100$ & 180 & High pressure drop, increased equipment costs, and ruptures [10] \\
Density $\left(\mathrm{kgL}^{-1}\right)$ & 1.2 & 0.85 & Higher density can cause pumping issues [7] \\
Oxygen content $(\mathrm{wt} \%)$ & $30-40$ & - & Bio-oils immiscible with petroleum based fuels [11] \\
Safety (flammable class) & 3 & 3 & Potentially harmful [13]
\end{tabular}


Table 2: Leaching reagents for demineralisation at 30 and $90{ }^{\circ} \mathrm{C}$

Leaching reagents

DI-water

$0.5,1,2.5,5,10 \%$ acetic acid

$0.5,1,2.5,5,10 \%$ formic acid ${ }^{\mathrm{a}}$

$1 \%$ sulphuric acid

$1 \%$ hydrochloric acid

$1 \%$ nitric acid

${ }^{\mathrm{a}} 0.5,2.5,5$ and $10 \%$ only tested at $30^{\circ} \mathrm{C}$ 
Table 3: Composition of biomass after leaching with different leaching acids

\begin{tabular}{|c|c|c|c|c|c|c|c|c|c|c|c|c|}
\hline \multirow{3}{*}{$\begin{array}{l}\text { Raw wood } \\
\text { Leaching temperature }\left({ }^{\circ} \mathrm{C}\right)\end{array}$} & \multicolumn{2}{|c|}{$\begin{array}{l}\text { Leaching yield } \\
(\%)\end{array}$} & \multirow{2}{*}{\multicolumn{2}{|c|}{$\begin{array}{l}\begin{array}{l}\text { Inorganic } \\
\text { content }(\%)\end{array} \\
0.41 \pm 0.04\end{array}$}} & \multirow{2}{*}{\multicolumn{2}{|c|}{$\begin{array}{l}\text { Acetyl content } \\
(\%)\end{array}$}} & \multirow{2}{*}{\multicolumn{2}{|c|}{$\begin{array}{l}\begin{array}{l}\text { Lignin } \\
(\%)\end{array} \\
28 \pm 1\end{array}$}} & \multirow{2}{*}{\multicolumn{2}{|c|}{$\begin{array}{l}\begin{array}{l}\text { Cellulose } \\
(\%)\end{array} \\
43 \pm 1\end{array}$}} & \multirow{2}{*}{\multicolumn{2}{|c|}{$\begin{array}{l}\text { Hemicellulose } \\
(\%)\end{array}$}} \\
\hline & - & - & & & & & & & & & & \\
\hline & 30 & 90 & 30 & 90 & 30 & 90 & 30 & 90 & 30 & 90 & 30 & 90 \\
\hline DI-water & 99.3 & 97.7 & 0.27 & 0.29 & 1.53 & 1.50 & 30 & 28 & 42 & 42 & 26 & 27 \\
\hline $1 \%$ acetic acid & 99.3 & 98.0 & 0.16 & 0.12 & 1.48 & 1.46 & 28 & 28 & 43 & 42 & 27 & 27 \\
\hline $1 \%$ formic acid & 99.0 & 97.9 & 0.14 & 0.11 & 1.53 & 1.41 & 28 & 31 & 42 & 42 & 26 & 26 \\
\hline $1 \%$ sulphuric acid & 99.3 & 92.0 & 0.11 & 0.10 & 1.36 & 0.80 & 29 & 32 & 42 & 43 & 27 & 22 \\
\hline $1 \%$ hydrochloric acid & 98.4 & 85.0 & 0.11 & 0.10 & 1.38 & 0.40 & 29 & 32 & 42 & 49 & 27 & 17 \\
\hline $1 \%$ nitric acid & 99.0 & 88.0 & 0.12 & 0.13 & 1.48 & 0.54 & 28 & 32 & 44 & 46 & 27 & 21 \\
\hline
\end{tabular}


Table 4: ICP-OES results for biomass leached at 30 and $90{ }^{\circ} \mathrm{C}$

\begin{tabular}{|c|c|c|c|c|c|c|c|c|c|c|c|}
\hline Element $^{b}(p p m)$ & Al & B & $\mathrm{Ca}$ & $\mathbf{F e}$ & $\mathbf{K}$ & Mg & Mn & $\mathbf{N a}$ & $\mathbf{P}$ & $\mathbf{S}$ & Zn \\
\hline Raw wood & 70.9 & 3.1 & 756.0 & 81.5 & 524.9 & 204.0 & 51.4 & 60.3 & 146.6 & 63.0 & 6.8 \\
\hline \multicolumn{12}{|l|}{ Leachings at $30{ }^{\circ} \mathrm{C}$} \\
\hline DI-water & 48.3 & 2.2 & 647.6 & 44.6 & 142.1 & 173.1 & 45.6 & 50.7 & 107.2 & 40.5 & 6.1 \\
\hline $1 \%$ acetic acid & 58.2 & 2.1 & 198.6 & 76.9 & 18.1 & 38.6 & 9.1 & 42.7 & 111.8 & 41.2 & 2.7 \\
\hline $1 \%$ formic acid & 54.6 & 1.9 & 133.8 & 63.8 & 19.2 & 18.5 & 3.4 & 44.8 & 114.5 & 43.7 & 1.4 \\
\hline $1 \%$ sulphuric acid & 42.1 & 1.2 & 52.8 & 44.3 & 9.5 & 12.3 & 1.4 & 42.4 & 112.0 & 82.8 & 2.4 \\
\hline $1 \%$ nitric acid & 48.9 & 0.8 & 47.5 & 51.3 & 10.5 & 11.9 & 1.3 & 42.4 & 111.3 & 45.6 & 1.2 \\
\hline $1 \%$ hydrochloric acid & 62.8 & 0.9 & 84.3 & 68.4 & 11.6 & 18.4 & 1.8 & 43.4 & 115.2 & 46.3 & 0.8 \\
\hline \multicolumn{12}{|l|}{ Leachings at $90^{\circ} \mathrm{C}$} \\
\hline DI-water & 46.7 & 1.3 & 685.2 & 48.5 & 99.8 & 172.6 & 45.2 & 51.7 & 100.9 & 41.9 & 9.8 \\
\hline $1 \%$ acetic acid & 39.8 & 0.5 & 190.9 & 32.2 & 15.5 & 30.1 & 8.4 & 43.8 & 100.7 & 41.1 & 4.6 \\
\hline $1 \%$ formic acid & 47.6 & 0.3 & 90.4 & 23.9 & 9.4 & 14.4 & 2.0 & 43.5 & 102.6 & 44.2 & 1.2 \\
\hline $1 \%$ sulphuric acid & 40.6 & 0.3 & 32.6 & 12.9 & 7.7 & 7.3 & 0.7 & 42.9 & 91.2 & 71.1 & 1.3 \\
\hline $1 \%$ nitric acid & 39.6 & 0.3 & 33.6 & 11.7 & 7.9 & 7.4 & 1.0 & 42.7 & 88.1 & 47.5 & 1.2 \\
\hline $1 \%$ hydrochloric acid & 48.0 & 0.3 & 32.2 & 12.8 & 9.6 & 7.7 & 0.9 & 43.2 & 86.9 & 46.4 & 1.1 \\
\hline
\end{tabular}

${ }^{\mathrm{b}}$ Elements below 2 ppm are not displayed, these include $\mathrm{Ba}, \mathrm{Cd}, \mathrm{Cr}, \mathrm{Cu}, \mathrm{Li}$, Ni and V. Elements tested and not detected were As, Co and Pd. 
Table 5: Mass balance of elements for $1 \%$ acetic acid leached biomass at $30{ }^{\circ} \mathrm{C}$

\begin{tabular}{llllllllllll}
\hline Element $(\mathbf{m g})$ & Al & $\mathbf{B}$ & $\mathbf{C a}$ & $\mathbf{F e}$ & $\mathbf{K}$ & $\mathbf{M g}$ & $\mathbf{M n}$ & $\mathbf{N a}$ & $\mathbf{P}$ & $\mathbf{S}$ & $\mathbf{Z n}$ \\
\hline In 70 g of raw biomass & 5.0 & 0.2 & 52.9 & 5.7 & 36.7 & 14.3 & 3.6 & 4.2 & 10.3 & 4.4 & 0.5 \\
In 70 g of 1\% acetic acid leached biomass & 4.1 & 0.1 & 13.9 & 5.4 & 1.3 & 2.7 & 0.6 & 3.0 & 7.8 & 2.9 & 0.2 \\
Calculated mass balance for ion removal & 0.9 & 0.1 & 39.0 & 0.3 & 35.5 & 11.6 & 3.0 & 1.2 & 2.4 & 1.5 & 0.3 \\
Measured amount in the leachate & 1.7 & 2.0 & 44.9 & 0.6 & 46.6 & 12.6 & 3.0 & 9.6 & 3.3 & 1.9 & 0.5 \\
\hline
\end{tabular}


Table 6: Elemental analysis of biomass after torrefaction at varying temperatures

\begin{tabular}{lllll}
\hline Temperature $\left({ }^{\circ} \mathbf{C}\right)$ & Carbon $(\boldsymbol{\%})$ & Hydrogen $(\%)$ & Nitrogen $(\%)$ & Oxygen $(\%)$ \\
\hline Raw & $50.4 \pm 0.7$ & $6.0 \pm 0.2$ & $0.10 \pm 0.00$ & $43.1 \pm 0.8$ \\
$\mathbf{2 2 0}$ & 51.1 & 5.9 & 0.09 & 42.9 \\
$\mathbf{2 3 0}$ & 51.1 & 6.0 & 0.11 & 42.8 \\
$\mathbf{2 4 0}$ & 51.5 & 5.9 & 0.11 & 42.5 \\
$\mathbf{2 5 0}$ & 52.4 & 5.9 & 0.11 & 41.6 \\
$\mathbf{2 6 0}$ & 53.4 & 5.9 & 0.11 & 40.6 \\
$\mathbf{2 7 0}$ & 54.8 & 5.9 & 0.11 & 39.3 \\
$\mathbf{2 8 0}$ & 55.9 & 5.8 & 0.11 & 38.2 \\
$\mathbf{2 9 0}$ & 58.7 & 5.6 & 0.09 & 35.7 \\
\hline
\end{tabular}


Table 7: Yields from the torrefaction of demineralised biomass

\begin{tabular}{|c|c|c|c|c|c|c|c|c|c|c|c|c|c|}
\hline \multirow{2}{*}{$\begin{array}{l}\text { Leaching reagent } \\
\text { Leaching temperature }\left({ }^{\circ} \mathrm{C}\right)\end{array}$} & \multirow{2}{*}{$\begin{array}{l}\text { Raw } \\
-\end{array}$} & \multicolumn{2}{|c|}{ DI-water } & \multicolumn{2}{|c|}{$1 \%$ acetic acid } & \multicolumn{2}{|c|}{$1 \%$ formic acid } & \multicolumn{2}{|c|}{$1 \%$ nitric acid } & \multicolumn{2}{|c|}{$\begin{array}{l}1 \% \text { sulphuric } \\
\text { acid }\end{array}$} & \multicolumn{2}{|c|}{$\begin{array}{l}1 \% \text { hydrochloric } \\
\text { acid }\end{array}$} \\
\hline & & 30 & 90 & 30 & 90 & 30 & 90 & 30 & 90 & 30 & 90 & 30 & 90 \\
\hline Moisture content (wt\%) & 24.9 & 24.8 & 24.9 & 24.8 & 24.9 & 25.2 & 24.9 & 24.6 & 24.8 & 24.9 & 24.7 & 24.9 & 24.7 \\
\hline \multicolumn{14}{|l|}{ Yields (g) } \\
\hline Liquid & 7.3 & 7.2 & 7.2 & 7.4 & 7.5 & 7.4 & 7.8 & 7.7 & 6.5 & 7.9 & 7.5 & 7.5 & 7.3 \\
\hline Biomass & 27.5 & 27.4 & 27.4 & 27.2 & 27.5 & 27.6 & 27.4 & 27.2 & 27.7 & 27.3 & 27.5 & 27.5 & 28.1 \\
\hline Gas (by difference) & 1.5 & 1.3 & 1.2 & 1.0 & 0.8 & 1.1 & 0.6 & 0.9 & 1.3 & 0.9 & 0.7 & 0.9 & 0.8 \\
\hline \multicolumn{14}{|l|}{ Yields, dry Basis (wt\%) } \\
\hline Liquid & 0.5 & 0.4 & 0.7 & 0.9 & 1.2 & 0.4 & 2.2 & 2.2 & 0.0 & 2.3 & 1.9 & 1.3 & 0.5 \\
\hline Biomass & 94.5 & 95.3 & 95.7 & 95.3 & 96.1 & 95.7 & 95.6 & 94.6 & 97.3 & 94.5 & 96.0 & 95.6 & 96.9 \\
\hline Gas (by difference) & 5.1 & 4.3 & 3.7 & 3.7 & 2.7 & 3.9 & 2.1 & 3.2 & 2.7 & 3.2 & 2.1 & 3.1 & 2.6 \\
\hline \multicolumn{14}{|l|}{ Analysis } \\
\hline $\mathrm{pH}$ & 2.5 & 2.5 & 2.6 & 2.5 & 2.7 & 2.6 & 2.6 & 2.6 & 2.6 & 2.5 & 2.7 & 2.5 & 2.9 \\
\hline
\end{tabular}


Table 8: Total loss in yield and structural analysis of biomass after demineralisation and torrefaction

\begin{tabular}{|c|c|c|c|c|c|c|c|c|c|c|c|c|c|c|}
\hline \multirow{3}{*}{$\begin{array}{l}\text { Torrefaction only } \\
\text { Leaching temperature }\left({ }^{\circ} \mathrm{C}\right)\end{array}$} & \multicolumn{2}{|c|}{$\begin{array}{l}\text { Overall biomass } \\
\text { yield } \\
(\%) \\
\end{array}$} & \multicolumn{2}{|c|}{$\begin{array}{l}\text { Acetyl after } \\
\text { leaching } \\
(\%)\end{array}$} & \multicolumn{2}{|c|}{$\begin{array}{l}\text { Acetyl after } \\
\text { torrefaction } \\
(\%) \\
\end{array}$} & \multicolumn{2}{|c|}{$\begin{array}{l}\text { Acetyl } \\
\text { change }^{c} \\
(\%)\end{array}$} & \multicolumn{2}{|c|}{$\begin{array}{l}\text { Lignin } \\
(\%) \\
\end{array}$} & \multicolumn{2}{|c|}{$\begin{array}{l}\text { Cellulose } \\
(\%) \\
\end{array}$} & \multicolumn{2}{|c|}{$\begin{array}{l}\text { Hemicellulose } \\
(\%) \\
\end{array}$} \\
\hline & \multicolumn{2}{|c|}{$94.5 \pm 1.5$} & \multicolumn{2}{|c|}{$1.51 \pm 0.03$} & \multicolumn{2}{|c|}{$1.32 \pm 0.05$} & \multicolumn{2}{|l|}{14.4} & \multicolumn{2}{|c|}{$34.7 \pm 0.5$} & \multicolumn{2}{|c|}{$41.5 \pm 0.9$} & \multicolumn{2}{|c|}{$21.2 \pm 0.6$} \\
\hline & 30 & 90 & 30 & 90 & 30 & 90 & 30 & 90 & 30 & 90 & 30 & 90 & 30 & 90 \\
\hline DI-water & 94.5 & 93.5 & 1.53 & 1.50 & 1.34 & 1.39 & 14.2 & 7.9 & 35.0 & 32.6 & 39.0 & 42.2 & 23.5 & 23.5 \\
\hline $1 \%$ acetic acid & 94.6 & 94.3 & 1.48 & 1.46 & 1.29 & 1.40 & 14.7 & 4.3 & 34.5 & 37.0 & 40.9 & 37.1 & 23.5 & 23.5 \\
\hline $1 \%$ formic acid & 94.8 & 92.9 & 1.53 & 1.41 & 1.31 & 1.24 & 16.8 & 13.7 & 36.3 & 38.0 & 39.7 & 38.1 & 22.9 & 22.9 \\
\hline $1 \%$ nitric acid & 93.7 & 85.6 & 1.48 & 0.54 & 1.29 & 0.54 & 14.7 & 0.0 & 35.9 & 38.6 & 41.6 & 39.4 & 20.5 & 20.5 \\
\hline $1 \%$ sulphuric acid & 93.8 & 88.3 & 1.36 & 0.80 & 1.23 & 0.73 & 10.6 & 9.6 & 36.7 & 36.8 & 42.1 & 41.0 & 19.7 & 19.7 \\
\hline $1 \%$ hydrochloric acid & 94.1 & 82.4 & 1.38 & 0.40 & 1.18 & 0.42 & 16.9 & -4.8 & 37.4 & 41.7 & 39.6 & 41.1 & 14.9 & 14.9 \\
\hline
\end{tabular}


Table 9: Comparison between torrefaction of raw biomass and $1 \%$ acetic acid leached biomass

\begin{tabular}{|c|c|c|c|c|c|c|c|}
\hline \multicolumn{8}{|c|}{ Torrefied biomass (no leaching prior) } \\
\hline $\begin{array}{l}\text { Temperature } \\
\left({ }^{\circ} \mathbf{C}\right)\end{array}$ & $\begin{array}{l}\text { Biomass loss } \\
(\mathrm{wt} \%)\end{array}$ & $\begin{array}{l}\text { Acetyl } \\
(\mathrm{wt} \%)\end{array}$ & $\begin{array}{l}\text { Lignin } \\
(\text { wt\%) }\end{array}$ & $\begin{array}{l}\text { Total sugars } \\
(\mathrm{wt} \%)\end{array}$ & $\begin{array}{l}\text { Carbon } \\
(\mathrm{wt} \%)\end{array}$ & $\begin{array}{l}\text { Hydrogen } \\
(w t \%)\end{array}$ & $\begin{array}{l}\begin{array}{l}\text { Oxygen } \\
(w t \%)\end{array} \\
\end{array}$ \\
\hline 240 & $5.5 \pm 1.5$ & $1.32 \pm 0.05$ & $34.7 \pm 0.5$ & $62.7 \pm 1.1$ & 51.5 & 5.9 & 42.5 \\
\hline 250 & $8.6 \pm 1.0$ & $1.23 \pm 0.03$ & $38.7 \pm 2.7$ & $59.0 \pm 1.5$ & 52.4 & 5.9 & 41.6 \\
\hline 260 & $11.4 \pm 2.1$ & $1.16 \pm 0.18$ & $40.6 \pm 3.2$ & $57.9 \pm 1.1$ & 53.4 & 5.9 & 40.6 \\
\hline 270 & $15.6 \pm 2.0$ & $0.95 \pm 0.11$ & $44.0 \pm 2.8$ & $53.8 \pm 2.2$ & 54.8 & 5.9 & 39.3 \\
\hline 280 & $19.8 \pm 1.5$ & $0.76 \pm 0.08$ & $49.2 \pm 4.2$ & $50.1 \pm 2.9$ & 55.9 & 5.8 & 38.2 \\
\hline \multicolumn{8}{|c|}{$1 \%$ acetic acid leached and torrefied biomass } \\
\hline $\begin{array}{l}\text { Temperature } \\
\left({ }^{\circ} \mathbf{C}\right)\end{array}$ & $\begin{array}{l}\text { Biomass loss }{ }^{\mathrm{d}} \\
(\mathrm{wt} \%)\end{array}$ & $\begin{array}{l}\text { Acetyl } \\
(\text { wt\%) }\end{array}$ & $\begin{array}{l}\text { Lignin } \\
(\text { wt\%) }\end{array}$ & $\begin{array}{l}\text { Total sugars } \\
(\mathrm{wt} \%)\end{array}$ & $\begin{array}{l}\text { Carbon } \\
(\mathrm{wt} \%)\end{array}$ & $\begin{array}{l}\text { Hydrogen } \\
\text { (wt\%) }\end{array}$ & $\begin{array}{l}\begin{array}{l}\text { Oxygen } \\
(w t \%)\end{array} \\
\end{array}$ \\
\hline 240 & $5.4 \pm 1.1$ & $1.29 \pm 0.13$ & $34.5 \pm 3.9$ & $64.0 \pm 1.7$ & 51.4 & 5.9 & 42.6 \\
\hline 250 & $7.6 \pm 0.7$ & $1.12 \pm 0.16$ & $34.9 \pm 1.8$ & $64.2 \pm 1.8$ & 52.2 & 5.9 & 41.8 \\
\hline 260 & $10.3 \pm 2.1$ & $0.83 \pm 0.15$ & $35.5 \pm 1.1$ & $62.5 \pm 2.5$ & 53.4 & 5.8 & 40.7 \\
\hline 270 & $14.0 \pm 0.6$ & $0.74 \pm 0.03$ & $39.5 \pm 5.8$ & $59.1 \pm 1.9$ & 53.6 & 5.8 & 40.6 \\
\hline 280 & $17.8 \pm 1.5$ & $0.71 \pm 0.05$ & $45.8 \pm 4.4$ & $51.8 \pm 1.8$ & 55.2 & 5.8 & 39.0 \\
\hline
\end{tabular}




\section{List of Figures:}

Figure 1: Pre-treatment sequence for the fast pyrolysis of biomass to bio-oil

Figure 2: Apparatus for pre-treating biomass prior to pyrolysis

Figure 3: Inorganic reduction after leaching with varying acetic and formic acid concentrations Figure 4: Inorganic reduction after leaching with varying acid types and concentrations

Figure 5: Inorganic fraction in biomass after leaching with $1 \%$ acetic acid for various residence times

Figure 6: Wood chips $6 \mathrm{~mm}$ and smaller (left) and biomass knife-milled to under $2 \mathrm{~mm}$ (right)

Figure 7: Biomass fibre analysis when varying the residence time of torrefaction at $245^{\circ} \mathrm{C}$

Figure 8: Effect of temperature during torrefaction for $20 \mathrm{~min}$ 


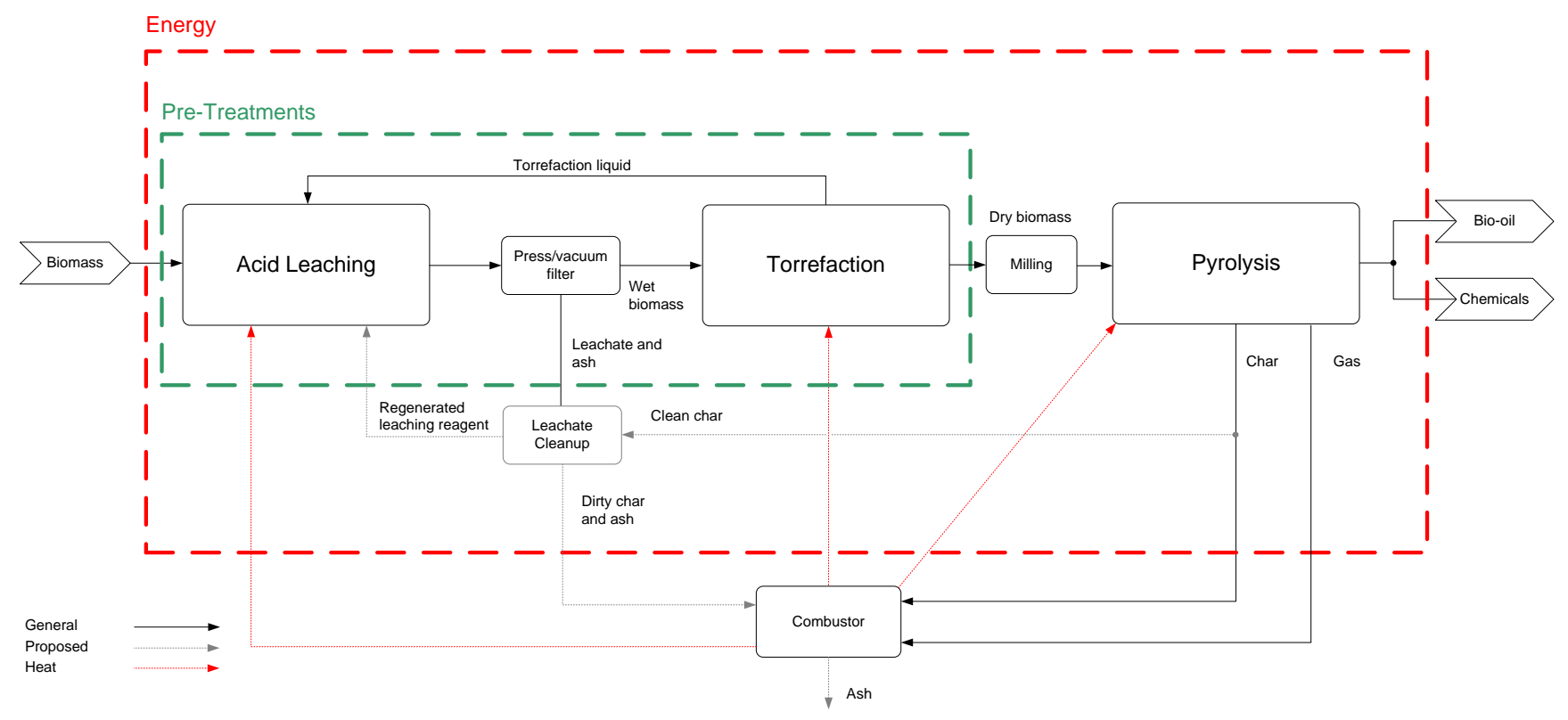

Figure 1: Pre-treatment sequence for the fast pyrolysis of biomass to bio-oil 


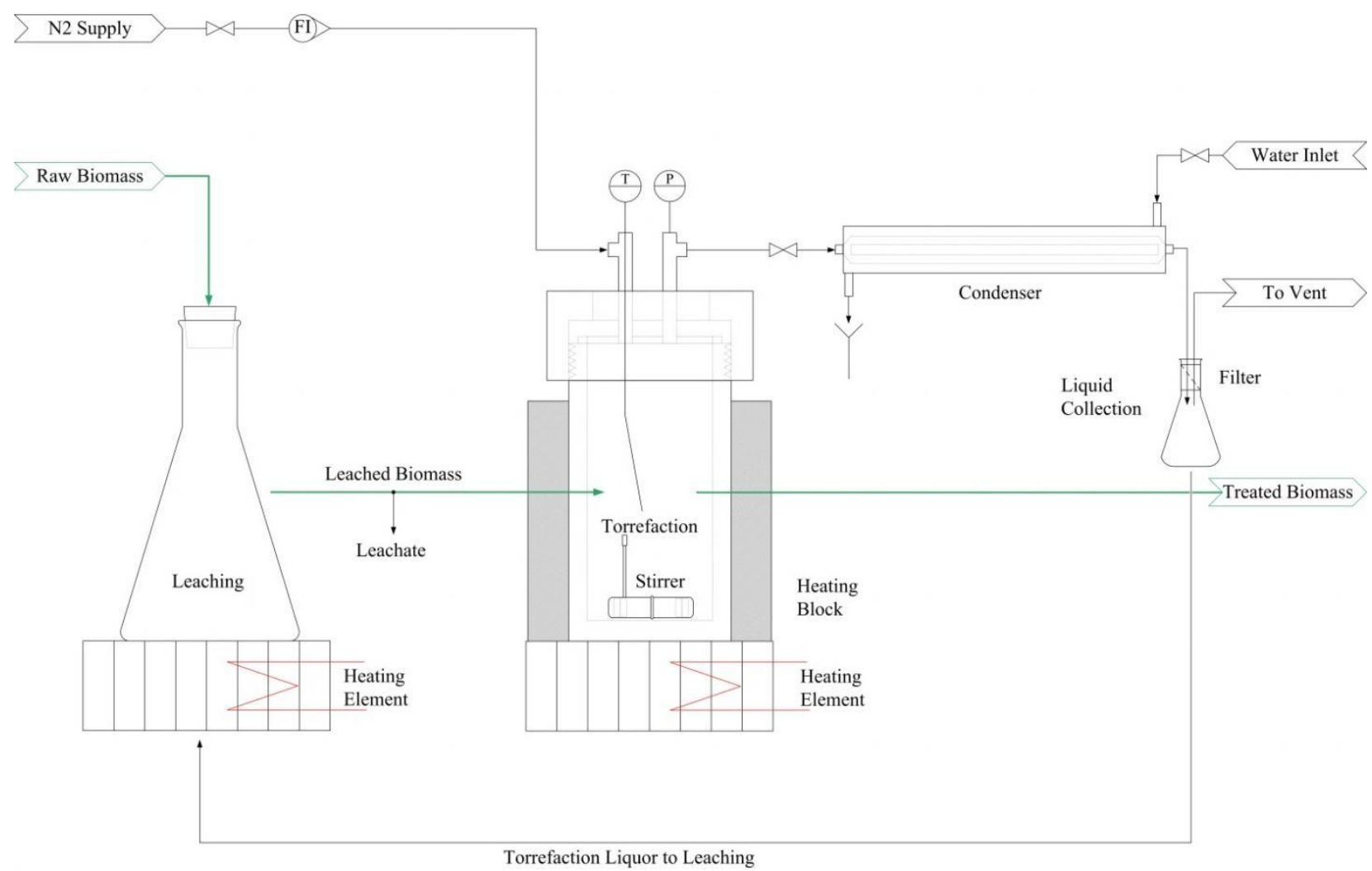

Figure 2: Apparatus for pre-treating biomass prior to pyrolysis 


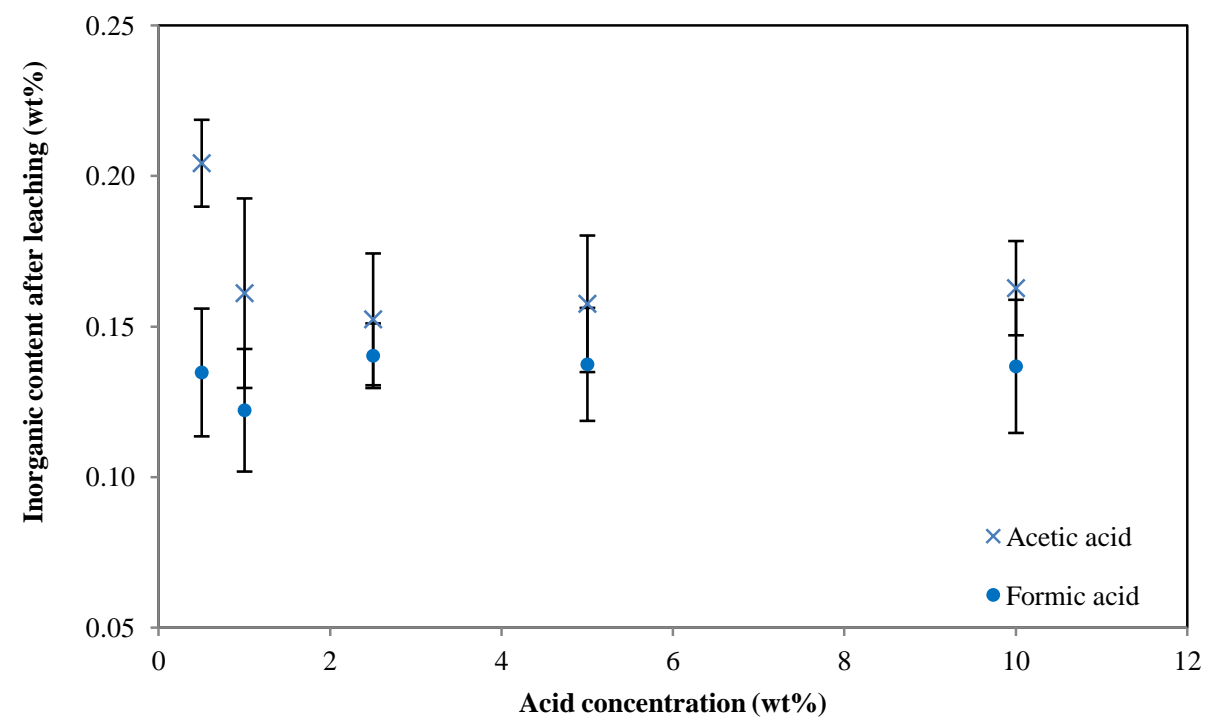

Figure 3: Inorganic reduction after leaching with varying acetic and formic acid concentrations 


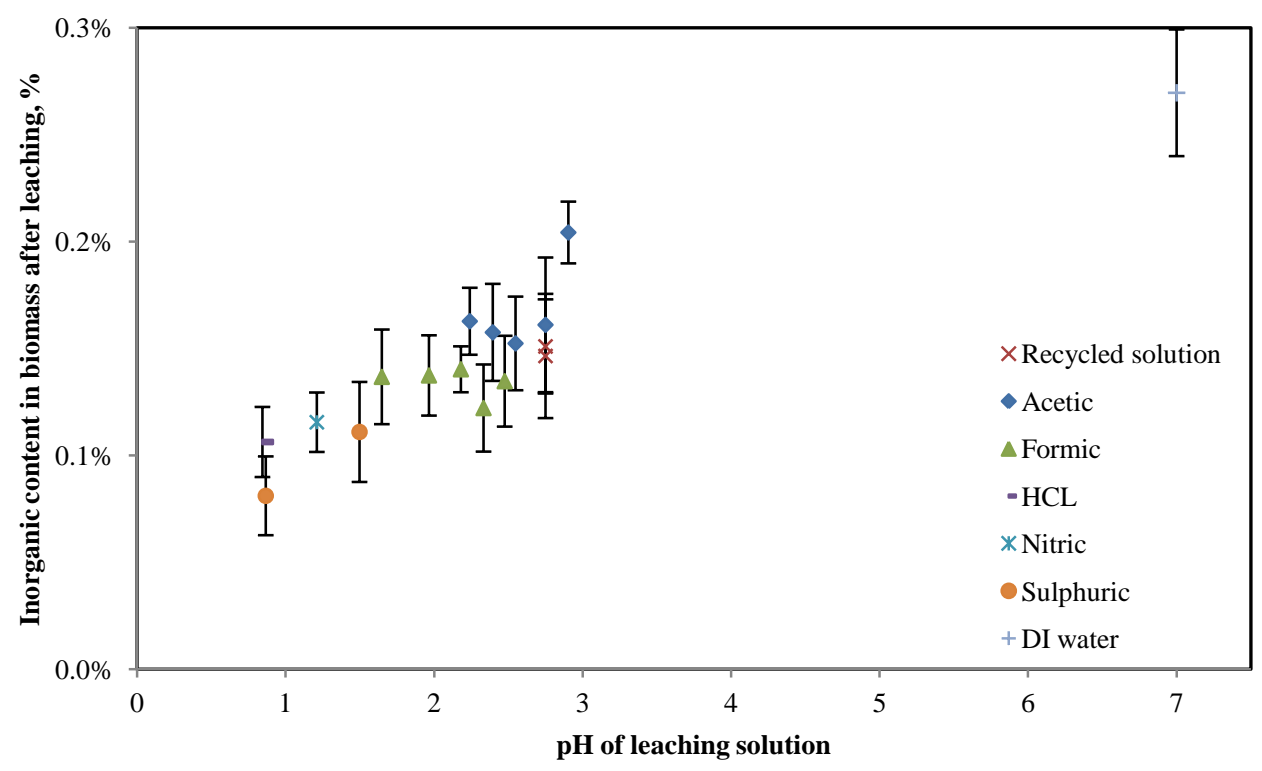

Figure 4: Inorganic reduction after leaching with varying acid types and concentrations 


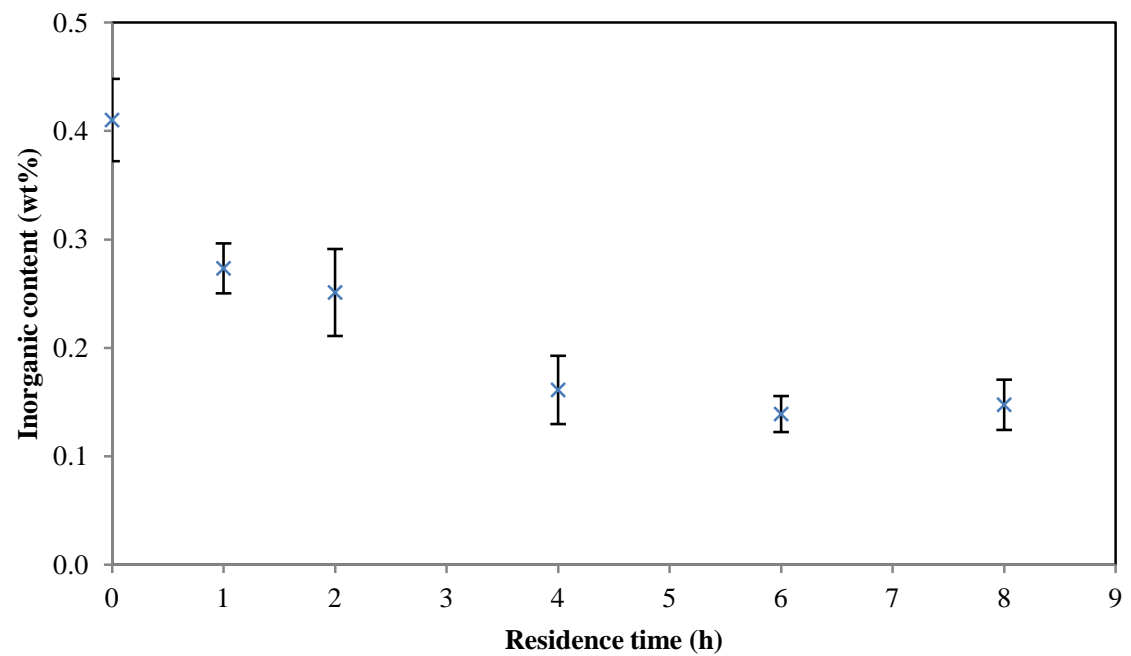

Figure 5: Inorganic fraction in biomass after leaching with $1 \%$ acetic acid for various residence times 


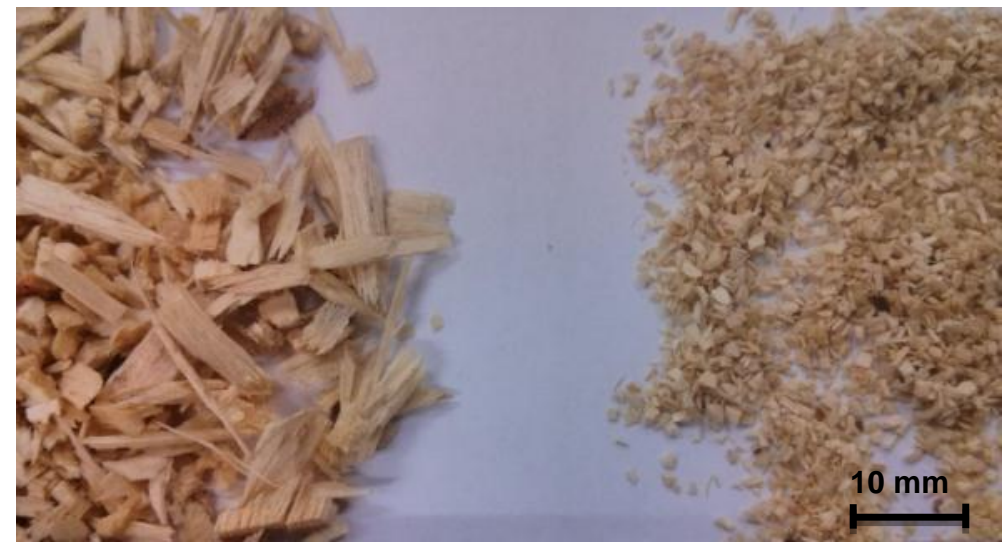

Figure 6: Wood chips $6 \mathrm{~mm}$ and smaller (left) and biomass knife-milled to under $2 \mathrm{~mm}$ (right) 


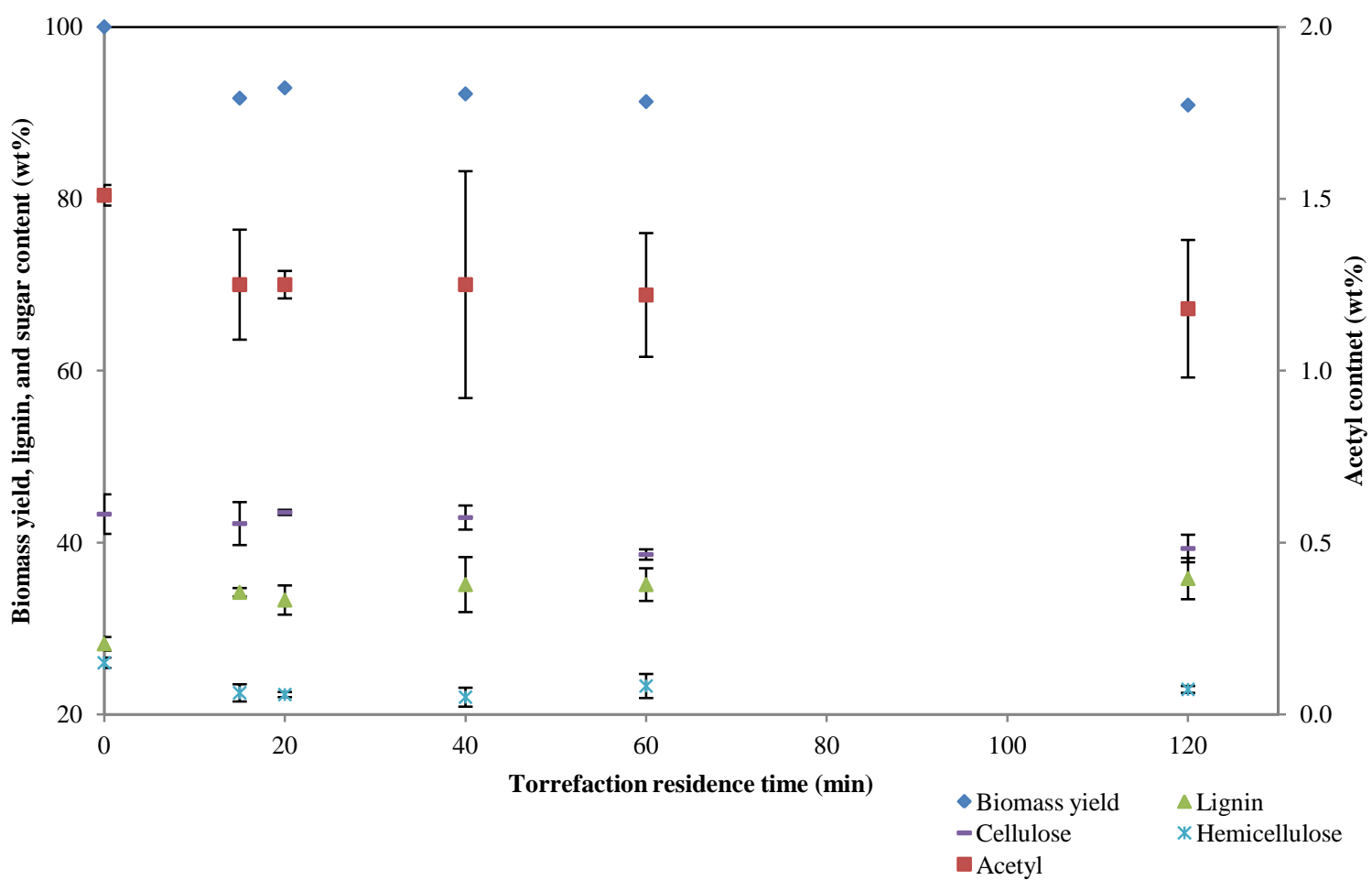

Figure 7: Biomass fibre analysis when varying the residence time of torrefaction at $245{ }^{\circ} \mathrm{C}$ 


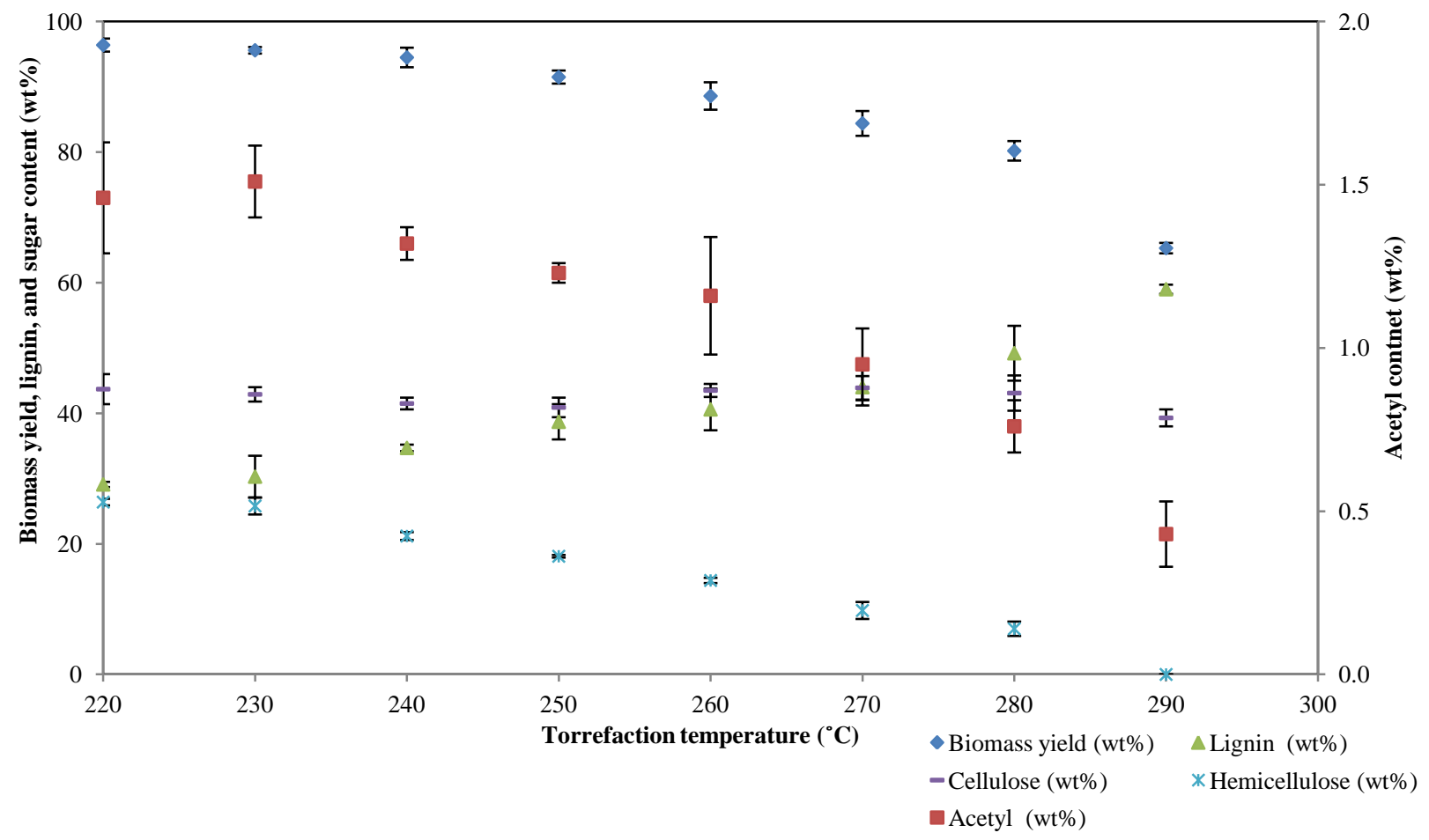

Figure 8: Effect of temperature during torrefaction for $20 \mathrm{~min}$ 


\section{Highlights}

- Pre-treatments were used to improve the properties of biomass

- These consisted of acid leaching and/or torrefaction

- Torrefaction liquor was recycled as the acid leaching reagent

- Pre-treatments decreased the ash, oxygen, moisture and acetyl content of raw biomass 